\title{
Regional Trade Blocs, Location Advantage And Enterprise Competitiveness In The Global Economy
}

\author{
John Oghenechuko Ogbor \\ Faculty of Management Sciences \\ Department of Business Administration \& Marketing \\ Delta State University, Asaba Campus, Asaba \\ Delta State, Nigeria \\ Edward G. Eromafuru \\ Faculty of Social Sciences \\ Department of Business Administration \\ Delta State University \\ Abraka, Delta State, Nigeria
}

\begin{abstract}
This paper examines the competitiveness of enterprises located in the Sub-Saharan region in the context of the relationship between regional trade blocs, location advantages and the competitiveness of the enterprises in the global economy. First, we examine the concept of regional trade blocs in the context enterprise competition in the global economy. Second, we examine the drivers of enterprise competitiveness in regional trade blocs and their location advantages. Third, we examine the historical and economic context of regionalization of trade and economic activities including the associated location advantages. Fourth, we examine regional trade blocs in the context of the experience of sub-Saharan Africa. Fifth, we examine the experience of subSaharan Africa as it relates to the location advantages associated with it. Specifically, the relationship between common political ideology and praxis, geographically closeness, common socio-cultural experience, common historical experience, infrastructure, clusters and enterprise competitiveness are examined. Research questions are phrased/constructed around the above five themes. Method of research is a "thick description" of the literature on the above subject matter. We also employ a critical discursive approach in interpreting what has been written in these areas in order to explore the gap in the knowledge concerning trade regionalization, location advantage and enterprise competitiveness in the context of Sub-Sahara African economy. Finally, recommendations are offered in terms of how African governments and policy-makers can provide an enabling environment, capable of turning the SubSaharan region to a regional location advantage for enterprise competitiveness.
\end{abstract}

Keyword: Location advantage, global economy, globalization, regional trade blocs, enterprise competitiveness, entrepreneurship, Sub-Saharan Africa.

\section{INTRODUCTION: THE GLOBAL ECONOMY AND ECONOMIC DEVELOPMENT}

We are moving away from a world in which national economies were once seen as relatively self-contained entities, isolated from each other by barriers to cross-border trade and investment; by distance, time zones, and language; and by national differences in government regulation, culture, political ideologies and business practices (McGrew, 201; Porter, 2000). And we are moving toward a world in which barriers to cross-border trade and investment are tumbling; perceived distance is shrinking due to advances in transportation and telecommunications technology; material culture is starting to look similar the world over; and national economies are merging into an interdependent global economic system (Smelser and Swedberg, 2005; Gereff, 2005; Gough and Venkataramany, 2006). The process by which this is 
occurring is commonly referred to as globalization (Ogbor, 2002; Gough and Venkataramany, 2006). Similarly, we will call this period as "the globalization era."

Similarly, globalization is defined as "a process which generates flows and connections, not simply across nation-states and national territorial boundaries, but between global regions, continents and civilizations." This invites a definition of globalization as: "an historical process which engenders a significant shift in the spatial reach of networks and systems of social relations to transcontinental or interregional patterns of human organization, activity and the exercise of power" (McGrew, 2012, p. 327). Ogbor (2001) and Ogbor and Orishede (2015) see the era of globalization as the ongoing period in which the state of a nation's economy is based on worldwide interdependence of resource supplies, product markets, and business competition.

In this paper, globalization is conceptualized as a process of interaction and integration among the people, companies, and governments of different nations; a process driven by international trade and investment and aided by information technology.

The concept of globalization, according to Maha, Frunza and Mursa (2013) "refers to the growing interdependence of countries, resulting from the increasing integration of trade, finance, investments, labor markets and ideas in one global marketplace (the global economy). The most important elements of this process are the international trade and the cross-border investment flows." The integration of the world economy has increased the specialization of workers, while national the companies compete in global markets. The trend is explained, mostly, by the substantially declining of the trade barriers as a result of successive trade negotiation rounds under the auspices of the GATT/WTO, unilateral trade liberalization and regional trade agreements (Smelser and Swedberg, 2005). Although there are global connections between all the countries, the strongest political and economic integration is being created within a few specific regions of the world: Europe, North America and South East Asia. Fundamentally, it could be argued that the culmination of this exercise or process of globalization is what has come to be known as the global economy (Walters, 2009; Smelser and Swedberg, 2005).

Various developments in the global economy have created opportunities for the growth of entrepreneurship. This is especially true for national governments and individuals who are able to seize the opportunities presented by the process of globalization. On the other hand, certain developments in the global economy have come to be seen as threats to economic development especially in the context of developing and underdeveloped economies. These developments or factors driving economic development are expanded cross-national cooperation and the intensification/reinforcement of regional trade blocs (Gough and Venkataramany, 2006); the preeminence of information technology, global communication, the Internet boom and the emergence of the World Wide Web; MNEs and the growing trend in the outsourcing of means of production by major global and multinational corporations (Gereff, 2005), and the diminishing role of the nation-state (Ogbor, 2002)

The major objective of this paper is to explore the linkage between three key factors of globalization/the global economy as they affect development in sub-Saharan Africa in the context of economic development in the region. The paper is a discourse of the pattern of economic development in Africa in the context of the global economy. Specifically, we want to examine (i) the ongoing intensification and reinforcement of the phenomenon of regionalization/formation of regional trade blocs and its role in economic development in sub- 
Saharan Africa; (ii) the diminishing role of the nation-state and its consequences for economic development, especially in the context of sub-Saharan Africa; (iii) the set of competitive problems encountered by the sub-Saharan region in terms of its spatial, historical and economic location in the global economy; and (iv) the strategic options at the disposal of subSaharan region in order to achieve a sustainable competitive advantage in the global economy.

Research questions were constructed around the above four themes: (i) what role(s) does the formation and intensification of regional trade blocs have on economic development in subSaharan Africa; (ii) what is the role of the nation-state in economic development in the context of sub-Saharan Africa; (iii) what are the challenges and problems confronting the economies of sub-Saharan Africa in the context of the global economy; and (iv) what possible strategic options do sub-Saharan Africa need to achieve strategic advantage in the global economy?

\section{Regional Trade Blocs and Location Advantage}

Different forms of trade have been in existence for thousands of years. Whether or not one is analyzing the trade routes of antiquity or modern times, trade and commerce have played a vital role in business expansion (Gough and Venkataramany, 2006; Urata, 2014; and Feingberg, 2012). Modern times have witnessed the birth of a global economy. Countries today engage in some form of global trade. Although, the United States has led the world in the new global economy, many countries are finding value in grouping together to form a regional free trade bloc or alliance. Two well known trade blocs are the European Union (EU) and the North American Free Trade Agreement. According to McGrew (2012), these two blocs are creating huge spheres of influence not only for their member countries, but also for the global economy at large.

Research and practical experience have indicated that regional trading blocs (RTBs) or Free Trade Agreements (FTAs) provide countries with the ability to exchange goods with member countries with minimal or no tariffs or cumbersome trade regulations (Bonapace, 2010).

Although, the EU and NAFTA are older more established Free Trade Agreements (FTAs), many other regional blocs are imitating their structures and purpose (Gereff, 2005). The Association of East Asian Nations (ASEAN) and the Common Market of the South (MERCOSUR) whose members are not solitary economic powerhouses have forged together with other developing nation-states in hope of creating a successful regional trade bloc This phenomenon is happening all over the world. Every continent beside Antarctica has been affected by the concepts of regional trade blocs and free trade association (Urata, 2014; Ogbor, 2002; Macdissi, 2004).

The history of Free Trade Agreements FTAs), which formed the basis for regional trade blocs, can be traced to the years immediately after World War II. Although, some would argue that regional trade blocs or Free Trade Association (FTAs) could be linked to Woodrow Wilson's unfortunate failure of the United Nation's parent organization, the League of Nations. Beginning with the Industrial Revolution the world has been slowly moving towards a global economy (Smelser and Swedberg, 2005). Many of the precursors to World War II were created due to an economic reliance between the United States - the lender, the United Kingdom - the borrower, and Germany - the payee (Gereff, 2005). This triangle of economies led to the Great Depression, which many believe was an indirect cause of World War II (McGrew, 2012).

After World War II, the United States emerged as a superpower with excellent resources and a stable and developed economy. The US after WWII developed a rebuilding model for post war 
Western and Central Europe better known as the Marshall Plan. The Marshall Plan was named after United State Secretary of State George C. Marshall. His plan led to the regional economic cooperation between Central and Western European countries. The United States offered up to $\$ 20$ billion for relief, but only if the European nations could get together and draw up a rational plan on how they would use the aid. For the first time, they would have to act as a single economic unit; they would have to cooperate with each other (Marshall Plan, 2005). Marshall also offered aid to the Soviet Union and its allies in Eastern Europe, but Stalin denounced the program as a trick and refused to participate. The Russian rejection probably made passage of the measure through Congress possible. The philosophy outlined by the Marshall Plan is the beginning of modern day regionalism and globalization (Feingberg, 2012).

The end of World War II created an environment suited for an expansion in the world economy. The creation of the General Agreement on Tariffs and Trade (GATT) accelerated multilateral trade. In postwar years the pace of globalization was quickened by the multilateral trade negotiations of the General Agreement on Tariffs and Trade (GATT); the liberalization of trade and investment; and the deregulation and privatization of national industries (Urata, 2002). GATT played a decisive role in the creation of Regional Trade Agreements (RTAs). Through the unitary principles of GATT, states were allowed to trade with other states utilizing one set of rules or directives. Upon its creation in 1948, states have lowered or eliminated tariffs and import fees. According to Macdissi (2004), this has helped spawn the creation of the global economy. Since the GATT was implemented in 1948 there have been eight "rounds" of global trade talks, each involving more countries, and taking liberalization further. These global trade talks ultimately created the World Trade Organization (WTO), which rigidly regulates trade conflicts and disputes (Sangmoon and Eui-Hang, 2012). Unlike, its predecessor GATT, the WTO is a stable organization with an agreed upon power to firmly regulate global commerce and trade. The World Trade Organization (WTO) is the only international organization dealing with the global rules of trade between nations. Its main function is to ensure that trade flows as smoothly, predictably and freely as possible (www.wto.org, 2005). Although, the WTO is free of direct control by any nation-state, changes in its rules and regulations must be approved by members' respected parliamentary processes.

According to Gough and Venkataramany (2016), Free Trade Agreements were primarily formed to increase trade between neighboring countries. The reference below showcases a theory behind regional integration. One well-recognized method for classifying the different types of regional integration is to categorize them by their stage of development, a method which focuses on the degree of integration, which is the one adopted here. From order of looser to stronger integration, there are: (1) FTAs, which remove tariffs and quotas within the group; (2) Custom unions, which establish common tariffs for countries outside this group; (3) Common markets, which lift restrictions on the movements of factors of production within the region; and (4) Economic unions in which common macroeconomic policies are adopted (Urata, 2014).

An examination of the growth and process of regional trade blocs or Free Trade Associations indicates that the formation of regional trade blocs is the foundation for nation-states to formalize a sense of regional cooperation. According to Macdissi (2004), regional trade blocs or FTAs have the ability to homogenize regional attributes and lessen regional economic threats; a location advantage. By members having a sense of cooperation, intra and inter regional trade can promote growth within states and between states. This expands the importance of the particular region (Walters, 2009). In many cases, regional trade blocs are bands of smaller countries whose individual trade would be minuscule to the economies of 
nations or other regional trade blocs or associations similar to United States and the European Union. However, the affiliation affords them greater opportunities than they could possibly acquire as individual nation states. The United States, a former naysayer, is beginning to see the advantages of regional integration by joining regional trade blocs or FTAs (Gough and Venkataramany, 2005).

\section{The Force Behind the Drive for Regional Integration}

A pertinent question that comes to mind is: Why this sudden push towards regional integration? One of the possible answers to that question is that the creation of a unified Europe has created a need for regional cooperation, especially, in developing regions similar to Latin and South America and the different sub-regions in sub-Saharan Africa (Ogbor and Orishede, 2015). And, as Gough and Venkataramany (2005:51) put it, "The EU has created an urgency to regionalize. Similarly, the EU's members are beginning to take a lion's share of world exports and imports far surpassing the United States. If nations-states fail to form productive regional alliances, other regional cooperation's will dictate world commerce. Moreover regional alliances can promote regional products native to only that region's part of the world. Nation-states can use the regional trade associations to effectively promote current markets or create new ones."

There are several internal and external reasons why there is a surge to form regional trade bloc (RTBs) or free trade associations (FTAs). External factors include securing markets and providing export opportunities for domestic companies by dismantling the trade barriers between participating countries (Urata, 2002). With the expansion of production, nation-states participating in regional or free trade associations are allowing themselves to increase their exporting, thus creating stronger home markets. According to Sangmoon and Eui-Hang (2012), successful regional trade blocs or associations have created a rapidly moving trend toward the creation of regional trade agreements. Many nation-states feel compelled to join a regional trade bloc or free trade association for fear of not being included or being at a comparative disadvantage with other nation-state that are members of a free trade association or region. This cycle in itself is creating the environmental push towards regionalization (Ogbor, 2002; Ogbor and Orishede, 2015).

Internal factors pressing nation-states towards regional trade bloc membership are positive indicators in economic growth through increased efficiency from competition (Urata, 2002). The lack of competition can allow companies to become lethargic or ant-competitive, which can slow the growth of an economy (Draper, 2010). Since the 1970's, policymaker's have come to recognize the benefits of liberalization of foreign trade and investment, deregulation and the removal of domestic regulations have facilitated high economic growth in the developing countries of East Asia, as well as industrial nations such as the US and the UK (Urata, 2002). The efficiency of markets pushes many nation-states to form or join regional trade agreements. The regional cooperation provides new options for economic expansion of domestic products. The market based economy will wean out the weaker companies and elevate the efficient companies. Regional trade blocs and free trade associations have allowed many nations-states to liberalize their foreign trade and investment.

Economic unions are the strongest form of regional economic cooperation. The European Union is a perfect example of what an economic union would resemble. An economic union has all the characteristics of an FTA or regional trade bloc and a common market; however, it goes a bit farther with additional macro-economic principles, such as a unified currency. The European Union established this January 1, 2002. Although, having a unified currency is not the only prerequisite or condition required of an economic union, but it is one of extreme 
importance (Carrere, Wilson and de Melo, 2010).

FTAs and regional trade blocs provide nation-states with the ability to increase foreign direct investment and their economical output through mutually beneficial RTAs. As mentioned previously in this paper, RTA's are categorized by the amount of power the trade bloc may have over its member nations. As pointed out by Sangmoon and Eui-Hang (2014), FTAs are simply free trade zones, which have the ability to increase trade among nations with fewer or less regulations. Furthermore, regional trade blocs provide a sound alternative to multilateral trade under the WTO (OECD, 2004). The WTO has been under immense scrutiny by various groups protesting its existence. However, FTAs and regional trade blocs are a viable substitute. According to Crocker, et al (2012), one particular reason why nation-states prefer the structure of regional trade blocs over the WTO's multilateral trade is the size and amount of participants. Third, another reason why countries are opting for FTAs is related to the size of membership as FTAs involve fewer participants. It is also much easier under a FTA to establish rules from new issues that are not yet under discussion in the WTO (Urata, 2002). FTA's are a potential format, which will allow for global trade without tariffs and cumbersome regulations. However, regional economic cooperation must begin as a FTA and gradually move to an economically stronger regional trade agreement, such as, an economic union. Following the path of regional economic evolution, the WTO will eventually be afforded many of the needed global trade polices that will enhance global commerce (Feingberg, 2012).

\section{Current Regional Trade Block Free Trade Agreements/Associations}

Regional Trade blocs or agreements as outlined earlier serve various purposes, which include access to the global economy; currency stabilization; and economic strength through mutual relationships with regional participants. It appears that the 1990's witnessed a boom in FTA organizations. Nation-states were forming some form of regional trade with neighbors and allies. By the end of September 2001, 239 regional trade agreements (RTAs) had been notified to GATT, or its successor the World Trade Organization (WTO). Of those agreements, 100 have been notified since the creation of the WTO in 1995 after the Uruguay Round of negotiations. A considerable number of these RTAs did not last long, however, and as of 31 January 2002, 162 agreements remained in force (Urata, 2002). With almost every nation-state having some interaction with a RTA, they are proving to be a vital part of globalization and the global economy (Sangmoon and Eui-Hang, 2012). Although, regionalism is separate from globalization, it would be hard to argue that they are not interconnected. However, and parallel to this globalization, we observe the development of a regional way, with the setting up of regional bloc, comparable to the success of the European Union (Macdissi, 2004). Macdissi explains the parallel course that regionalism is taking with globalization. One could argue that regionalism is causing the acceptance and push towards globalization and developments in the global economy. Nation-states feel safer going the course with other states rather than going it alone. This is a part of human nature "strength in numbers". We would go even farther and make a case that regionalism's ultimate output is globalization (Fernandez and Portes, 2013). With regionalism, the authors believe globalization would not be moving at the speed it is currently enjoying.

Regional trade arrangements can be further explained through contrasting and comparison. The four biggest regional trade blocs: (the EU, NAFTA, MERCOSUR, and ASEAN) accounted for about two thirds of world export trade" (Macdissi, 2004). Their impact and membership will undoubtedly shape the future of globalization and the global economy. In the context of regional trade blocs and economic integration, economic and entrepreneurial growth is impacted in a profound way. First, economic integration resulting from regional trade blocs 
creates trade. Such effects are the shifting of resources from inefficient to efficient companies as trade barriers fall (Ogbor and Orishede, 2015). Production shifts to more efficient producers for reasons of comparative advantage, allowing consumers access to more goods at a lower price than would have been possible without integration. Companies that are protected in their domestic markets face real problems when the barriers are eliminated and they attempt to compete with more efficient producers. The strategic implication is that companies that might not have been able to export to other countries - even though they might be more efficient than producers in that country - are now able to export when the barriers come down. Thus, there will be a demand for their products, and the demand for the protected, less efficient products will fall. Regional trade blocs and economic integration can result to trade diversion (Urata, 2014). Trade diversion occurs when trade shifts to countries in the group at the expense of trade with countries not in the group, even though nonmember companies might be more efficient in the absence of trade barriers.

Integration also results in the overall growth in the market and companies within that group through economies of scale as firms can produce more cheaply (Draper, 2010). Another important effect is the increase in efficiency due to increase competition. This is especially true in the apparel and furniture industries in Mexico (Brown, Khan and Shaheen, 2009). When NAFTA was created, many apparel and furniture manufacturing companies left the United States and Canadian to Mexico. The Mexican textile industry brought jobs back from Asia countries like Malaysia and Singapore as labor rates increase and U.S. textile firms set up operations in Mexico to supply both the Mexican and U.S. apparel markets. The transfer of knowledge and technology to the Mexican textile industry by U.S. firms led to a multiplier effect thus making the Mexican textile industry more competitive in the world market (Clapham, 2001).

Closer trade and economic association among countries, according to Kelly (2005), are likely to stimulate multiple-country entrepreneurial activity. In the European Union and NAFTA settings, entrepreneurs have emerged as major "change agents" taking advantage of new combinations to open new markets, provide new sources of supply, suggest new methods of production, and in some cases stimulate the reorganization of entire industries (Collier and Venables (2008). Such opportunities are expected to emerge as global entrepreneurship creates larger, more efficient productive bases, new sources of comparative advantage, and the increased international competitiveness of firms in regional trade blocs.

\section{REGIONAL INTEGRATION AND COMPETITIVENESS OF THE AFRICAN ECONOMY How it all Started}

Historically, the Economic Commission for Africa (ECA) can be seen as the champion of regional integration in Africa. Already in the mid-1960s, the organization has proposed the division of Africa into regions for the purposes of economic development (Macdissi, 2004). Current African integration arrangements can be divided into two broad groups: those that fit into the Lagos Plan of Action (LPA) adopted in April 1980, and those that were either in existence or came about outside the LPA. The Lagos Plan was promoted by the ECA and launched in a special initiative by the OAU ((McCarthy, 2005). It envisaged three regional arrangements aimed at the creation of separate but convergent and over-arching integration arrangements in three sub-Saharan sub-regions. West Africa would be served by the Economic Community of West African States (ECOWAS) which pre-dated the Lagos Plan. A Preferential Trade Area (PTA) was established in 1981 to cover the countries of East and Southern Africa, which was eventually replaced in 1993 by the Common Market for Eastern and Southern Africa (COMESA). For Central Africa the treaty of the Economic Community of Central African States (ECCAS) was approved in 1983 but remains to be fully ratified. Together with the Arab 
Maghreb Union (AMU) in North Africa, these arrangements were expected to lead to an allAfrican common market by the year 2025. The Lagos Plan was followed up in 1991 by the Abuja Treaty, re-affirming the commitment of the OAU's Heads of State to an integrated African economy (McCarthy, 2005). In April 2001, African Heads of State launched the African Union to replace the OAU.

\section{The Experience of Regional Integration and Competitiveness of the African economy}

Although regional integration is increasingly recognized as the viable space within which small economies can better organize themselves to survive economically in a highly competitive global economy, sub-Saharan Africa has been lacking in the formation of viable regional trade blocs (Kelly, 2005; Draper, 2010; Brown and Khan, 2009; Mkandawire, 2001). Although the launch of the African Union (AU) and the New Partnership for Africa's Development (NEPAD) have given new impetus to the integration process, political instability in the region has made the development of a viable trade bloc almost impossible.

A factor crucial to the success of any economic integration and development process in subSaharan Africa is a peaceful political environment. As has been noted by a number of authors (e.g., Himbara, 1994; Nicholas, 1994; Reinikka and Svensson, 1999), economic growth can only materialize in an environment of peace, security and stability. The poor economic performance of the Sub-Saharan region and the slow pace of regional integration are in part the result of civil unrest, conflict and war in several countries of the region.

As in other developing countries, the bulk of the financial resources of the ECOWAS, EAC, SADC and other countries in Sub-Saharan Africa are derived from export revenue from commodities such as coffee, cocoa, cotton, coffee, tea, petroleum, phosphate and bauxite. With the exception of South Africa and a few other countries in Sub-Saharan Africa, an additional source is external funding in the form of loans and official development assistance (Claphan, 2001). As a result, the performance of Sub-Saharan economies is heavily dependent on the external environment and, in particular, economic growth in the developed countries. Although many countries in other regional trade blocs are cooperating to reduce trade barriers among themselves, Sub-Saharan Africa, as producers of primary commodities, has become less competitive because primary commodity exports have become much less important as a viable source of trade. Consequently, the low price of raw materials in the global market negatively affected the growth of Sub-Saharan economies. These developments had repercussions on African countries, which are already weakened by the lack of economic diversification, the external debt burden, deteriorating terms of trade and persistent conflict (Collier and Venables, 2008; Chabal and Daloz, 1999).

Thus, many of the benefits commonly associated with regional trade blocs and the rationale for economic integration seem to be elusive in the context of sub-Saharan Africa. Specifically in the case of sub-Saharan Africa, experience has indeed shown that economic cooperation and integration do not prosper in an environment that is politically unstable and socially insecure. Peace and security are therefore pre-requisites for a balanced economic development and advancement as they largely determine the direction and pace of economic and political reforms of a country (Okolo and Wright, 2011).

Apart from political instability and other forms of social crises, the inability to have major regional trade blocs in Sub-Saharan Africa is derived from the fact that African countries have been struggling to establish a political identity, and the different trade associations or blocs have political as well as economic underpinnings (Mertzger, 2008; Thiese, 2013; Okolo and 
Wright, 2011). Second, the markets in sub-Saharan Africa, with the notable exception of South Africa, are underdeveloped, making trade liberalization a relatively minor contributor to economic growth in the region. Third, most African countries rely on trade links with former colonial powers than with each other, so intra-regional trade is not significant. This is particularly the case among Francophone and English-speaking West African countries.

We undertook the discussion in this section to reveal the relationship between the growing need for regional trade blocs as a response to increased global competition and the impact on economic development. From a global perspective, the historical and political development of the European Union and the economic objectives of NAFTA, ASEAN and other regional trade blocs indicate this relationship. From a comparative perspective, however, sub-Saharan Africa is yet to benefit economically from the advantages commonly associated with regional trade blocs. In this section, some of the reasons behind this failure have been identified.

Globalization is an historical inevitability, a point in man's socio-historical development that keeps generating its own logic and as such cannot end. It is also pointed out that an inevitable offshoot of the process of globalization is the emergence of regional trade blocs. An everincreasing proportion of trade is taking place between regional blocs as well as between transnational companies. Thus, regional trade associations or agreements will continue to be a form of response to competitive pressures occasioned by the workings of the global economy. In fact, the formation of regional trade blocs has become a historical replacement for empires. In one way or the other, regional trade blocs have become insulating capsules against the vagaries of globalization. Thus, customs unions and common markets are able to create conditions for absorbing the shocks of globalization (Steven, 2008). To this end, sub-Saharan Africa has no choice, therefore, but to speed the process of sub-regional and regional integration, for, globalization is not a passing phenomenon.

\section{THE NATION-STATE, COMPETITIVE ADVANTAGE AND ECONOMIC DEVELOPMENT}

The era of globalization has also brought in a new way of thinking about the role of the nationstate. To be sure, a nation-state refers to a single or multiple nationalities joined together in a formal political union (McGrew, 2012; Ogbor, and Orishede, 2015; Ogbor and Orishede, 2011). The nation-state determines an official language(s), a system of law, manages a currency system, uses a bureaucracy to order elements of society, and fosters loyalties to abstract entities like "Nigeria”, United States", "United Kingdom”, etc.

As pointed out in the foregoing sections, this is the era in which many nations have altered their philosophical directions and changed their economic assumptions. As old ideas are cast aside, new leaders have emerged while old leaders have decided to think about economic development in new ways. According to Brown, Khan and Shaheen (2009), the changes in politics, culture, increase in and expansion of information technology, liberalization of crossborder trade and resource movements, growing consumer pressures and expanded crossnational economic and political cooperation are visible in the many sudden and outright reversals of the conventional wisdom which says that the state has the absolute right to play a large role in the life of its citizens. In fact, the era of globalization has witnessed a shrinking role of the state in terms of economic development.

Gone are the days when many countries considered themselves as autonomous, self-contained, and self-sufficient entities when it comes to the production, distribution, and consumption of goods and services. Many people would agree that we all compete in a global economy based on worldwide interdependence of resource supplies, product or service markets, and business competition in which every country or nation-state depends on another nation-state for the 
exchange of goods and services. We have seen how governments have increasingly realized that cooperating with other countries through treaties and agreements in order to gain reciprocal advantages can enhance their own countries' interest (Smelser and Swedberg, 2005).

According to Ogbor (2001), in the global economy, every nation has a role to play in ensuring that it is not left behind in the quest for economic growth. In most instances, the role of the state and its competitiveness in the global marketplace depend on the availability of its factor endowment and how it uses this to create competitive advantage (that is, to compete with other nations). Importantly, traditional factor endowments such as land and abundant raw materials have become obsolete as many countries are creating their own factor endowments through investment in infrastructures that promote investments from global corporations. One reason is that today's products are no more national, but universal, because they rely on so many different technologies or inputs that are scattered across the globe (Porter, 2000). For a product, such as a PC to get to the consumer, its production occurs in many countries where the resources needed for its production are located. A country that provides such a resource has a factor endowment. A factor endowment is a nation's positioning factor of production such as skilled labor or the infrastructure necessary to compete in the global economy (Kelly, 200o5). South Africa, for example, realized that its factor endowment lies in the country's institutional framework upon which small businesses play a significant role in economic and entrepreneurial development (Draper, 2010).

Multinational enterprises from the developed countries are now locating their production facilities outside of their home countries such as in India and other Southeast Asian countries. This is particularly true not only in labor-intensive industries (such as the textile industry) but also in technological-driven ones (such as computer hard- and software as well as in information and communications technology). According to Porter (2000), many industries that utilize information technology are now locating their production facilities in China as well as in India where direct investments in these countries have promoted the development of local industries with local entrepreneurs taking charge of the process of production and exportation of these products to the developed countries. Other hitherto desert countries are now redirecting the conduct of international business to their shores through the provision of infrastructures such as modern ports and communication technology as in the United Arab Emirates. In order to remain competitive, many countries are trying to attract investments by offering a factor of production. What a country has to offer in order to be competitive in the global economy is that country's factor endowment (Okolo, 2011; Metzger, 2008).

Every nation has something unique which distinguishes it from other nations. A factor endowment is the extent to which a country is endowed with such resources as land, labor, capital, raw materials, technology, infrastructure, etc. As Ogbor (2001) has pointed out, the global economy is a terrain for the competitiveness of nations and their economies. It represents an arena through which the Darwinian doctrine of the survival of the fittest is manifested. Those nations that are able to survive in this global competition are those that are able to develop a unique competence through entrepreneurship. Porter (1999) indicates that it is this uniqueness that forms the basis for a nation's competitive advantage.

Thus, with regard to the globalization of the means of production, companies are increasingly dispersing parts of their production process to different locations around the globe to take advantage of national differences in the cost and quality of factors of production such as labor, energy, land, technology, infrastructure, and capital. The objective is to lower costs, boost 
profits, and to be competitive in the global economy. The relationship between the globalization of the means of production and entrepreneurial development in a nation is the trickle-down effect or multiplier effect that such production facilities have in those countries that have invested in infrastructures.

As a source of competitive advantage among nations, some countries are more supportive than others in terms of entrepreneurial development (Claphan, 2001). For instance, from Eastern European countries to Brazil, Chile, and South Africa, entrepreneurial ventures have been seen as the road towards the building of successful free market economies. New entrepreneurial ventures are emerging daily with the support of governmental efforts in these countries. Unfortunately, not every country makes it easy to start a new venture. Some countries such as Zimbabwe are still ingrained in the old ways of thinking about development, while others, such as Somalia and Sudan, are still involved in the politics of ethnic cleansing. Still others are trapped in the old ways of doing things with cultural and institutional aversion to risk-taking so necessary for entrepreneurship (Fernandez and Portes (2013). In other countries, the pervasive practice of depending on government employment is so ingrained that people are averse to take the initiatives to venture into entrepreneurship. However, the greatest obstacle lies in the inability of the nation-state to support entrepreneurial development through the provision of an enabling environment necessary for economic growth.

Some of the factors driving economic development and entrepreneurship in the global economy are beyond the control of individual initiatives. Factors such as national trade policies, foreign exchange policies, global market opportunities, availability of entrepreneurial education, provision of necessary infrastructure, security, acceptable interest rates, ecommerce and the emergence of the World Wide Web fall within the domain of national governments and global market conditions (Porter, 2000; Walters, 2009; McGrew, 2012). Hence the developed and industrialized nations of the world today are those that have responded to and provided the conditions necessary for economic growth.

This era of globalization has also witnessed a re-evaluation of development strategies in many developing countries in Sub-Saharan Africa as they try to support economic development through varieties of incentives. These, according to Kelly $(2005$, include direct financial support, the building of infrastructure, provision of an enabling environment for the growth of indigenous small businesses and entrepreneurs, and most importantly, appropriate socioeconomic and political ideology, including a sound ethical and regulatory environment (Ogbor and Ilori, 2011).

\section{PROBLEMS AND CHALLEGES FACING AN AFRICAN REGIONAL GROUPINGS}

Several researchers and authors (e.g., Chabal and Daloz, 1999; Draper, 2010; Kelly, 2005; Foroutan, 2012) have critically looked at the factors inhibiting African competitiveness in the global economy. For example, despite the multiplicity of groupings in the global economy, subSaharan regional groupings have not been very effective in terms of competitiveness in the global economy. Among the reasons provided by researchers for this ineffectiveness are the following:

- Intra-regional trade in Africa as a share of total foreign trade has traditionally been low compared to other regions. Figures in the early 1990s suggest that the proportion was only 8.4 per cent in 1993 compared with Western Europe (69.9 per cent), Asia (49.7 per cent), North America (33 per cent) and Latin America (19.4 per cent) (WTO source, quoted in McCarthy, 1995, p. 21).

- Most African states have suffered from severe macroeconomic disequilibria, foreign debt service burdens, over-valued currencies, lack of trade finance, and a narrow tax 
base, with customs duties a substantial source of revenue. The protective import substitution strategies adopted by most countries since independence resulted in a host of regulations restricting trade such as licensing, administrative foreign exchange allocation, special taxes for acquiring foreign exchange, advance import deposits etc (Ogbor, 1994; Mkandawire, 2001; World Bank, 2000, 2012). Thus the economic context has been unfavorable to the development of regional commitments.

- The design of African integration schemes around inward-looking industrialization meant that the economic costs of participation for member states are often immediate and concrete (in the form of lower tariff revenues and greater import competition), while the economic benefits are long-term and uncertain and are often unevenly distributed among member states (Chabal and Daloz, 1999).

- The dominance of a few countries and the huge disparities in size among members of regional groupings led to concerns about the distribution of benefits. Regions have found it difficult to address the equitable distribution of gains and losses from integration. Mechanisms to provide compensation to the less developed members of groupings have been either absent or ineffective (Clapham, 2001).

- The dependence of many African countries on their former colonial powers tended to work against viable regional groupings. The importance of North-South linkages (Franco-African and Commonwealth links and various Lomé Conventions) may have distracted commitment from intra-African groupings (Stevens, 2008).

- Regionalism has been driven from above by public sector organizations and has lacked the support and involvement of the private sector and the general public. Cooperation has been seen as involving bloated and expensive bureaucracies, rather than opportunities for growth and development (World Bank, 2014).

- Institutional weaknesses, including the existence of too many regional organizations, a tendency towards top-heavy structures with too many political appointments, failures by governments to meet their financial obligations to regional organizations, poor preparation before meetings, and lack of follow up by sectoral ministries on decisions taken at regional meetings by Heads of State (Metzger, 2008; Foroutan, 2012).

- Integration is hampered by the existence of weak states and political opposition to sharing sovereignty. Integration arrangements are not characterized by strong supranational bodies and virtually all integration institutions are intergovernmental (Claphan, 2001).

\section{CONCLUSION AND RECOMMENDATIONS}

In this paper, we have examined some of the factors shaping the competitiveness of the African entrepreneur in the global economy. Specifically, the paper examines the challenges and constraints that are rooted in global phenomena such as regional integration and the diminishing role of the nation-state in the global economy.

It is argued that although many countries in other regional trade blocs are cooperating to reduce trade barriers among themselves, sub-Saharan Africa, as producers of primary commodities, has become less competitive because primary commodity exports have become much less important as a viable source of trade. Consequently, the low price of raw materials in the global market negatively affects the growth of sub-Saharan economies. Other factors that have hindered the development of a viable trade bloc among African countries are political instability and social unrest. Indeed, the paper argues that economic cooperation and integration do not prosper in an environment that is politically unstable and socially insecure. 
The era of globalization has also brought in a new way of thinking about the role of the nationstate as it has witnessed a shrinking role of the state in terms of economic development. In most instances, the role of the state and its competitiveness in the global marketplace depend on the availability of its factor endowment and how it uses this to create competitive advantage. What a country has to offer in order to be competitive in the global economy is that country's factor endowment. New entrepreneurial ventures are emerging daily with the support of governmental efforts in these countries. Some of the factors driving entrepreneurship in the global economy are beyond the control of individual initiatives.

On the basis of the above discussion and conclusion, the following recommendations can now be made.

Peace and security are important pre-requisites for a balanced economic development and advancement as they largely determine the direction and pace of economic and political reforms of a country. African governments, policy-makers and opinion-builders must put in place necessary mechanisms that enhance peace in the region. What Sub-Saharan Africa needs first is the establishment of viable political systems that encourage collective initiatives, which in turn lead towards sustainable economic integration.

There is need for expanded regional markets in Sub-Saharan Africa. Large markets matter, especially for small economies and for least developed countries, because they create new investment opportunities, enhance the production of tradable commodities, and encourage the flow of foreign direct investment which could serve as the basis for local entrepreneurial initiatives.

Countries in sub-Saharan Africa must strive to bridge the global digital divide in order to be competitive in the global economy. The bridging of the global digital divide in this context is possible by: (i) providing better means of communication; (ii) integrating economic activities (specially Agro-business which represents 80 percent of African economic activities); (iii) making public services more efficient (usually named as E-Government, E-Health, E-education, etc.); (iv) improve infrastructure and productivity; and (v) improving democracy and participation mechanisms.

For sub-Saharan Africa to fully benefit from information and communication technologies (ICT), investment in broadband Internet and other robust information technology is necessary. Sub-Saharan Africa must invest in physical infrastructure (such as fiber optic-cable), in the human capital necessary to operate these systems, and in government regulatory agencies. These investments are likely to yield economic growth and improve living standards. This paper recommends that the policy of industrial clusters, as a tool for economic and entrepreneurial development, be aggressively pursued as past trade and investment policies such as structural adjustment programmes have worked against foreign direct investment from multinational enterprises and global corporations.

The discourse of regionalization and its praxis in the context of the global economy make perfect sense. People typically like to do business with reliable trustworthy partners. Nationstates are no different. Regional trade agreements provide a medium for reliable commerce to transact. Many of the arrangements are based on cultural and ethnic likeness, close proximity, and freer trade. For all the realities of globalization, nations cannot escape their own geohistory. Culture, religion, geography, ethnicity all combine to squarely place a given nation on a map surrounded by its neighbors who have been there through the millennia (Gough and Venkataramany, 2006) 
We have noted that some of the drivers of entrepreneurship and economic development such as national trade policies, foreign exchange policies, global market opportunities, availability of entrepreneurial education, provision of necessary infrastructure, security, acceptable interest rates, e-commerce and the emergence of the World Wide Web fall within the domain of national governments and global market conditions. Therefore, it is essential that national and state governments or the nation-state enter into active partnership with the private sector in order to facilitate the availability of the drivers of entrepreneurship. Because of nonavailability of financial resources among many Sub-Saharan African countries, it makes sense here that African governments enter into partnership with private initiatives in the context of public-private partnership (PPP) in the provision of infrastructures needed for economic and entrepreneurial development. Indeed availability of the ICT infrastructure (connectivity, computers, cell phones, etc) has been one of the ways in which governments, in partnership with private initiatives, are using technology to help African entrepreneurs. In a nutshell, this paper recommends that if sub-Saharan region is to gain competitive advantage in the global economy, policymakers must address the following issues which have partly accounted for the disadvantaged competitive position currently occupied by sub-Saharan Africa in the global economy:

- Overlapping memberships of competing groups should be resolved to allow a clear political commitment to particular country groupings.

- For a common market to function its members at least need to be at peace. The wars and conflicts in a number of African regions which have devastated transport networks, communications and other basic infrastructure need to be peacefully resolved.

- Ways must be found to involve the private sector in the integration process. It should not be expected that all private sector groups will favor regional integration. In some countries, farmers may fear low-cost competition from elsewhere in the region and may take quite a protectionist stance. The participation of consumer groups and other NGOs should be encouraged as these groups can also gain from exploiting the opportunities for greater intra-regional trade.

- Given the disparities in economic weight that exist between members of some groupings, new policy instruments to deal with the fears of economic polarization must be found, for example, multispeed arrangements (allowing weaker members more time to liberalize), compensation schemes and regional investment banks.

- Dispute settlement mechanisms need to be strengthened and ways to ensure policy credibility must be put in place. Investors need to have confidence that integration measures will not be reversed and that barriers to regional markets will not be reinstituted overnight. Binding liberalization commitments in the WTO should be encouraged where possible.

\section{References}

Bauer, P (2000), From Subsistence to Exchange - and other essays, Princeton University Press.

Bräutigam, D. (1998). "Local Entrepreneurship in Southeast Asia and Sub-Saharan Africa:

Networks and Linkages to the Global Economy," Conference Paper, (School of

Brown, O, SR Kahn, and FH Shaheen (2009), "Introduction”, in SR Kahn (ed.) Regional Trade Integration and Conflict Resolution. Routledge.

Carrere, C., Wilson, J. and de Melo, J. (2010). Distance and Regionalization of Trade for Low-income countries. Policy Research Working Paper, Washington, DC: The World Bank.

Chabal, P and J Daloz (1999). Africa Works: Disorder as Political Instrument, London: James Currey. 
Clapham, C (2001), "The Changing World of Regional Integration in Africa” in C Clapham, G Mills, A Morner, and E Sidiropoulos, Regional Integration in Southern Africa: Comparative International Perspectives, South African Institute of International Affairs.

Collier, P and T Venables (2008), “Trade and Economic Performance: does Africa's fragmentation matter?, Annual World Bank Conference on Development Economics, Cape Town, South Africa, June.

Crocker, Snow, Jr. \& Sullivan, P. (2013, January) Constructive regionalism: think globally, trade locally. World Paper, 1/16/2013.

Draper, P, D Halleson, and P Alves (2007), "SACU, Regional Integration, and the Overlap Issue in Southern Africa: From Spaghetti to Cannelloni?”, South African Institute of International Affairs, SAIIA Trade Policy Report No 15.

Draper, P (2010), "Rethinking the (European) Foundations of African Economic Integration: A Political Economy Essay", OECD Development Centre Working Paper, 293.

Edordu, C. C. (1999). “Trade Finance Export Development in Africa." Speech Delivered at the 10 $0^{\text {th }}$ Meeting of the Advisory Group held in Abidjan, Cote d'Ivoire (August 27, 1999). www.afreximbank.com/press (accessed on November 23, 2000).

European Union (1996), "The European Statute for SMEs," http://ec.europa.eu/enterprise/entrepreneurship/craft-priorities. (Accessed on March 15, 1999).

European Union (1998). The European Union, Enterprise and Industry, "Women Entrepreneurs and CoEntrepreneurs." http://ec.europa.eu/enterprise/entrepreneurship/craft/craft-women. (Accessed on March 15, 1999).

Feinberg, R.E. (2012). The political Economy of the United States' Free Trade Arrangements. World Economy, 26 (7): $22-38$

Foroutan, F. (2012). Regional Integration in sub-Saharan Africa. Policy Research Working Paper, Washington DC: The World Bank.

Gereff. G. (2005). The Global Economy: Organization, Governance, and Development. In N. J. Smelser and R. Swedberg (eds.). The Handbook of Economic Sociology. Princeton: Princeton University Press.

Gough, G. M. and Venkataramany (2006). Regional Economic Cooperation. International Business and Economic Research Journal, Vol. 5 (2): 49-60

Himbara, D. (1994). "Domestic Capitalists and the State in Kenya," in Bruce J. Berman and Colin Leys, eds. African Capitalists in African Development. Boulder, CO: Lynne Rienner Publishers.

Jensen, M. (2001). “Open Access for Africa. Challenges, Recommendations and Examples” United Nations ICT Task Force Working Group on the Enabling Environment. New York, NY.

Keating, R. J. (2000). “The Entrepreneurial View,” (Small Business and Entrepreneurship Council), http://www.sbsc.org/content/display (Accessed on February 14, 2001).

Kelly, D. (2005) “Trade, Security and Globalisation”, in Kelly, D. and Grant, W. The Politics of International Trade in the Twenty-First Century. Basingstoke: Palgrave Macmillan

Lesser, C. and Moisé-Leeman, E. (2009) “Informal Cross-Border Trade and Trade FacilitationReform in SubSaharan Africa”, OECD Trade Policy Working Papers, No. 86, OECD Publishing.

Lloyd, Peter, J (1992). Regionalization and World Trade. OECD Economic Studies, No. 18. Spring 1992.

Macdisson, C. M. (2004). Regionalization and Specialization: A Theoretical Contribution: Journal of American Academy of Business, 4 (1/2) 471-493,

Maha, Liviu-George G. and Frunza, Ramona and Mursa (2010), Globalization \& Regionalization in International Trade (April 8, 2013). Available at SSRN: http://ssrn.com/abstract $=1375116$ or http://dx.doi.org/10.2139/ssrn.1375116

McGraw, A.G. (2012). Global Legal Integration and Present-Day Patterns of Globalization. In V. Gessner and A.C. Budak (eds.). Emerging Legal Certainty on the Globalization of Law. Ashgate: Dartmouth Publishing Company.

Metzger, M. (2008). Regional Cooperation and Integration in Sub-Saharan Africa. Geneva: UNCTAD.

Mkandawire, T. (2001) "Thinking about developmental states in Africa”, Cambridge Journal of Economics, 25, 289313. 
Nicholas, M. S. (2004). “The State and Capitalism in Zimbabwe," in Bruce J. Berman and Colin Leys, eds. African Capitalists in African Development. Boulder, CO: Lynne Rienner Publishers.

Ogbor, J. O. and Orishede, F (2015). "Openness and Closure: The Dialectics and Contradictions of Globalization and the Development of African Entrepreneurship." Journal of Social and Management Studies. Vol. 10, No. 1, pp. 4454 .

Ogbor, J. O. and Orishede, F. (2011). "Structural Adjustment Programs in Africa: Dialectics and Contradictions." Trend Journal of Management and Social Sciences, Vol. 4, No. 2, pp. 108-117.

Ogbor, J. O. and Olori, W. (2011). "The African Entrepreneur: Cultural Discourses and Cultural Inhibitors." Trend Journal of Management Sciences. Vol. 4, No. 1, pp. 12-31.

Ogbor, (2002). "Understanding the Global Economy and its Competitiveness as Relations of Power," Competitiveness Review. Vol. 12, no. 2, pp. 24-56.

Ogbor, J. (1994), Structural Adjustment and the Politics of Adjustment: The Nigerian Foreign Exchange, Stockholm, Sweden, Norstedt. (Nos. of pages 398).

Okolo, J.E and Wright, S (2011). West African Regional Cooperation and Development (eds.), Oxford: Westview Press.

Onyeiwu, S. (2000). "Inter-Country Variations in Digital Technology in Africa. Evidence, Determinants and Policy Implications," United Nations University, World Institute for Development Economics Research (July 2000).

Opaku, J. (2000). “Background paper on ICT-for-Development in Africa," United Nations ICT

Task Force Working Group on the Enabling Environment. New York, NY.

Overseas Development Institute (2008) "Regional Integration in African, Caribbean and Pacific Countries: A Review of the Literature", September.

Pastor, R. A. (1998). “Wanted: A Real NAFTA Partnership,” Worth (March 10, 1998), http://www.worth.com/Editorial/Wealth-Management/Business. (Accessed on Dec. 14, 2010)

Porter, M. (2000). Location, Competition and Economic Development: Economic Economic Development Quarterly, 14 (1): 15-35.

Porter, M. (1998). "Clusters and the New Economics of Competition." Harvard Business Review (November/December, 1998).

Porter, M. (1990). The Competitive Advantage of Nations. New York: The Free Press.

Quaynor, N. N. (2000). “Africa's Digital Rights”, United Nations ICT Task Force UNICTTF III/2000/16.

Ruggie, J (1982), “International regimes, transactions, and change: Embedded liberalism in the postwar economic order", International Organization, 36 (2): 14-32.

Sally, R (1998), Classical Liberalism and International Economic Order: Studies in Theory and Intellectual History, London: Routledge.

Sangmoon, K. and Eui-Hang, S (2012). A Longitudinal Analysis of Globalization and Regionalization of Trade: A Social Network Approach. Social Forces, 8 (2): 445-468.

Smelser, N. J. and Swedberg, R. (2005). The Handbook of Economic Sociology (2nd edition). Princeton: Princeton University Press.

Smith, G. and Lindblad, C.(2000). “Mexico: Was NAFTA worth It?” Business Week, (December 22, 2000), BW Online version).

Stevens, L (2008). The Impact of Europe on the Maghred and sub-Saharan Africa. Journal of Common Market Studies, Vol. xxix, No. 2: 217-243.

Thisen, J.K. (2013). Alternative Approaches to Economic Integration in Africa. Africa Development. Vol. xiv, No. 1: 19-60.

UNCTAD (2009) Economic Development in Africa Report: Strengthening Regional Economic Integration for Africa's Development. United Nations: Geneva.

UNECA (2006), Assessing Regional Integration in Africa II: Rationalising Regional Economic Communities, Addis Ababa: United Nations Economic Commission for Africa and African Union. 
UNECA (2006), Assessing Regional Integration in Africa II: Rationalizing Regional Economic Communities, Addis Ababa: United Nations Economic Commission for Africa and African Union.

UNECA (2008), Assessing Regional Integration in Africa 2008: Towards Monetary and Financial Integration in Africa, Addis Ababa: United Nations Economic Commission for Africa. http://www.uneca.org/aria

Urata, Shujiro (2014). Globalization and the Growth in Free Trade Agreements. Asian Pacific Review, 9 (1): 22-36.

Walters, M. (2009). West Africa and Regionalization of Trade, New York: Oxford University Press.

Weisbrot, M., Baker, D. Kraev, E. and Chen, J. (2001). "The Scorecard on Globalization 1980-2000: Twenty Years of Diminished Progress," Center for Economic Policy and Research (July 11, 2001).

World Bank (2000), Trade Blocs, Policy Research Report, Oxford University Press. 